\title{
The Role of Purchasing Decisions Mediating Product Quality, Price Perception, and Brand Image on Customer Satisfaction of Kopi Janji Jiwa
}

\author{
Janes Rivai ${ }^{2}$ (iD $\triangle$ and Zulfitri ${ }^{2}$ 8 (D) \\ ${ }^{12}$ Mercu Buana University, Indonesia \\ $\bowtie$ Corresponding Author: Janes Rivai, E-mail: janes.rivai16@gmail.com
}

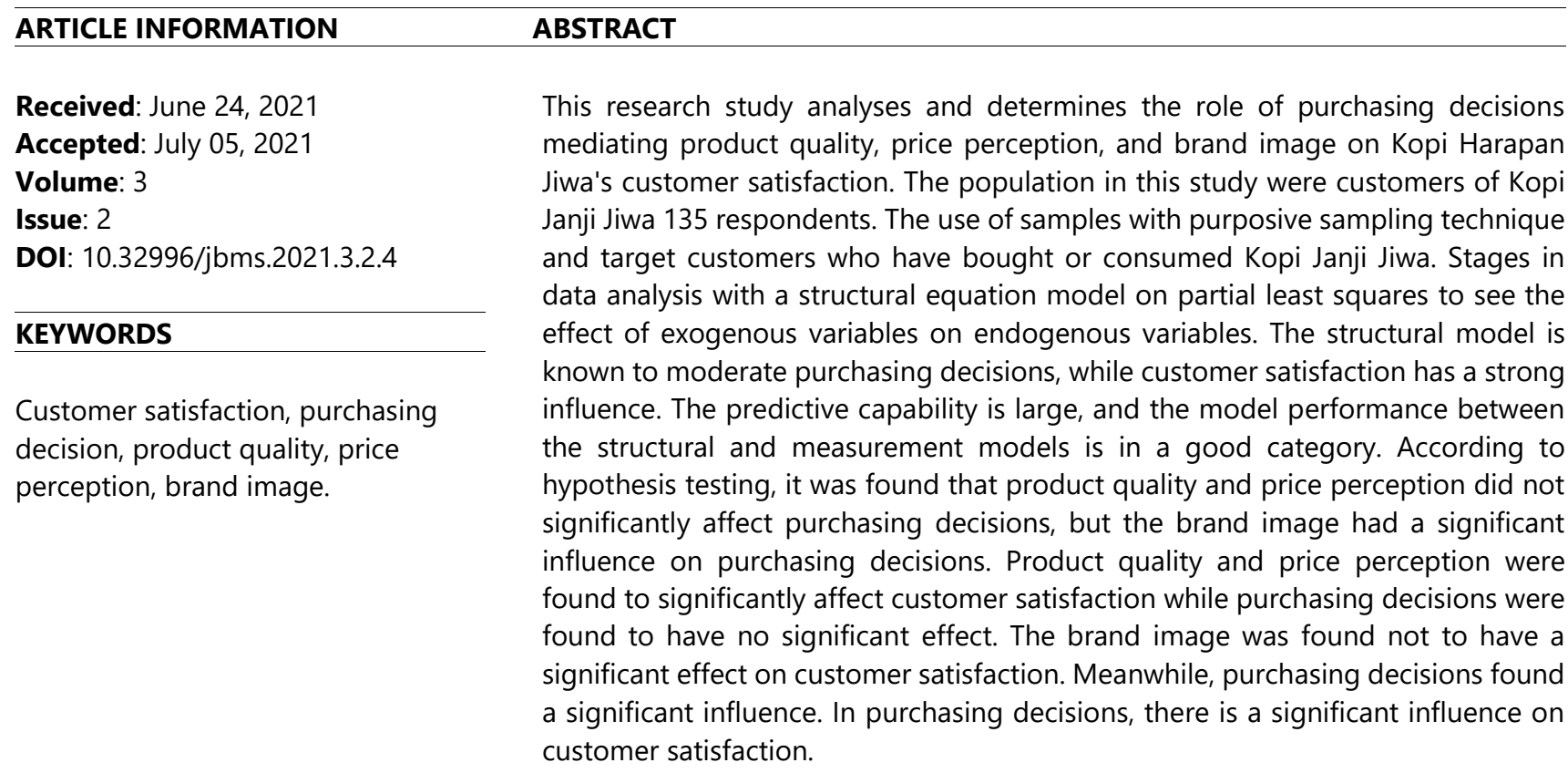

\section{Introduction}

The business growth of the national coffee industry in Indonesia has progressed rapidly from 2016 to 2020, with the demand for coffee drinks increasing. Current business developments cause people to follow current developments. For example, with a lifestyle change, there is a lifestyle change in the use of coffee, which is increasing rapidly, especially among this millennial generation. Coffee has become a drink that is currently widely popular in daily consumption of beverages, becoming a lifestyle trend of today's society. By enjoying the coffee of his choice and the right atmosphere in choosing a place to socialize or gather with colleagues or friends, it is a lifestyle that is developing at this time.

Indonesia has a known level of coffee consumption, reaching 4.6 million packages of coffee. The level of national coffee consumption can experience a significant increase from 2016 to 2021 with results in 2016 known to be 250 tons and it is predicted to increase by 350 tons in 2021. The big impact occurs due to increased coffee consumption, which impacts the emergence of business competition with various shops or cafes that provide or sell coffee to meet customer needs. Coffee businesspeople prioritize various coffee innovations to meet customer needs by providing the best quality coffee taste and being accepted by customers to give the impression of being satisfied with the products served. There are trigger factors in customer satisfaction in considering buying decisions.

Customers' buying decisions regarding products or services define purchasing decisions (Heryanto, 2021; Soleh, 2017). Dissatisfaction that often occurs in Kopi Janji Jiwa products is that the taste of the coffee served does not match or meet customer expectations or desires. Business people need to choose the right way to face business competitiveness by improving the quality of managed products as well as possible, with the perception of affordable prices with market share, and product

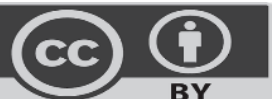

BY
Published by Al-Kindi Center for Research and Development. Copyright (c) the author(s). This open access article is distributed under a Creative Commons Attribution (CC-BY) 4.0 license 
brands that attract customers to consume these products.

Brand recognition with the right strategy will influence customers in making product purchasing decisions. The following is a comparison of local milk coffee brands:

Table 1. Local Milk Coffee Shop Brand Comparison

\begin{tabular}{|c|c|c|}
\hline No & Brand & Percentage (\%) \\
\hline 1 & Janji Jiwa & $39,90 \%$ \\
\hline 2 & Kenangan & $29,80 \%$ \\
\hline 3 & Kulo & $13,60 \%$ \\
\hline 4 & Fore & $5,10 \%$ \\
\hline
\end{tabular}

Source: www.topbrand-award.com (2020)

Kopi Janji Jiwa brand shows that it has a good existence compared to competing local coffee brands. Based on table 1, the comparison of local coffee milk shop brands, it is known that the largest brand of Kopi Janji Jiwa has a percentage of $39.90 \%$ compared to competing local coffee brands, namely Kopi Kenangan Mantan (29.80\%), Kopi Kulo (13.60\%), and Kopi Fore (5,10\%). During the Covid-19 pandemic, it had a major impact on the sales of Kopi Janji Jiwa. These sales decline greatly affected the company's sustainability to survive in the current unstable economic conditions.

The development of Kopi Janji Jiwa sales during 2020 experienced a decline in sales due to the Covid-19 pandemic. The following is the data on sales of Kopi Janji Jiwa during the pandemic period from January to October, which did not experience significant developments.

Table 2. Kopi Janji Jiwa Selling Data

\begin{tabular}{|c|c|c|c|}
\hline No & Month & Selling Total & Development (\%) \\
\hline 1 & January & 1385 & $-6,86$ \\
\hline 2 & February & 1290 & 2,09 \\
\hline 3 & March & 1317 & - \\
\hline 4 & April & - & - \\
\hline 5 & May & - & - \\
\hline 6 & June & - & $-14,19$ \\
\hline 7 & July & 1130 & 28,05 \\
\hline 8 & August & 1447 & $-1,79$ \\
\hline 9 & September & 1421 & 8,72 \\
\hline 10 & October & 1545 & \\
\hline
\end{tabular}

Source: Kopi Janji Jiwa Selling Data

Based on data on the selling of Kopi Janji Jiwa from January to October 2020, it is known that the level of purchasing decisions has decreased so that it has a direct impact on decreasing customer satisfaction. With a significant decline in selling, apart from the pandemic, other factors are considered by customers when purchasing Kopi Janji Jiwa.

The increasing purchasing decisions will make customer satisfaction increase. Several factors that influence purchasing decisions are brand image (Rayni Delya, 2020), price (Sejati \& Yahya, 2016), product quality (Soebakir et al., 2018), promotion (Siti Mabrur, 2019), product availability (Pakpahan, 2019), credibility (Yuniarti, 2016), location (Aulia, 2016).

The results of the pre-survey research involved 20 respondents, selected perceptions of price, product quality, and brand image which allegedly caused the purchase decision to decline. Based on previous related research from Bayu Sutrisna (2016), Andhalia (2020), Gilbert (2020), this study will analyze and find out "The Role of Purchasing Decisions Mediating Product Quality, Price Perception, and Brand Image on Customer Satisfaction of Kopi Janji Jiwa". 


\section{Literature Review}

Consumer Behavior

The process is carried out when individuals and groups use, choose, buy in, and satisfy customers' needs and desires (Schiffman \& Kanuk, 2008). The evaluation process will provide a view of the product or service, causing customers to feel satisfied and tend to remember the brand and be loyal to the brand.

\section{Purchasing Decision}

In the existence of a buying decision-making process, customers will consider supporting factors before deciding to buy a product or service (Schiffman \& Kanuk, 2008; Soleh, 2017). Behaviour shows that customer behaviour in using, searching for, and spending products and services expected to meet needs defines purchasing decisions.

\section{Consumer Satisfaction}

Satisfaction and dissatisfaction become a customer condition that arises because comparing the product with customer expectations (Philip Kotler et al., 2019). An emotional experience that occurs in customers in evaluating the direct experience of using a product or service is the definition of customer satisfaction.

\section{Marketing Management}

Companies try to pay attention to positive impressions for customers by building the right relationship with customers (Philip. Kotler et al., 2000). Planning, execution, determination of promotions, prices, services, and ideas in generating exchanges with a specific group, with the primary goal of satisfying customers, is the definition of marketing management.

\section{Product Quality}

Product quality is seen based on function and usability, namely reliability, convenience, durability, operation, accuracy, and product repair according to customer needs (Philip Kotler et al., 2019). Products that meet customer expectations can create a good experience for customers.

\section{Price Perception}

Customers see that pricing is an important aspect affecting the purchasing decision process (Saladin, 2007). An indicator that is seen based on the monetary amount given to customers for products or services for products that have been sold to customers is the definition of price perception.

\section{Brand Image}

A picture of the association and customer trust in the brand used, on the overall brand perception to form a knowledge of the brand that is taken into consideration in using a product or service is the definition of brand image (Tjiptono \& Diana, 2019).

\section{Hypothesis Development}

1) The Influence of Product Quality on Purchase Decisions

The products provided by the company make customers have an interest in buying or using the product ( $P$. Kotler \& Armstrong, 2014). Product describes the ability of a product to satisfy customer needs (Efendi \& Rois Arifin, 2018).

Based on previous research conducted by Nor Hazlin Nor Asshidin (2016), Muhammad Gigih (2019) stated that product quality significantly influences purchasing decisions. H1: Product quality has a positive and significant effect on purchasing decisions.

\section{2) The Influence of Price Perception on Purchase Decisions}

Customers will make purchasing decisions on products according to the perception of price and quality needed (Efendi $\&$ Rois Arifin, 2018). Price perception is one of the important aspects of customers in making purchasing decisions.

Based on previous research conducted by Owusu Alfred (2013), Suri Amili (2017) stated that price perception significantly influences purchasing decisions. H2: Price perception has a positive and significant effect on purchasing decisions.

\section{3) The Influence of Brand Image on Purchase Decisions}

Brand image is an association stage that is perceived over time as a direct and indirect experience of the purchased brand (Tjiptono, 2014). The brand image that is appropriately implemented will create a positive influence in understanding aspects of consumer behaviour in a purchase decision (Muharam \& Soliha, 1970).

Based on previous research conducted by Cristina Calvo-Porral (2017), Albari (2020) states that brand image significantly influences purchasing decisions. H3: Brand image has a positive and significant effect on purchasing decisions. 
4) The Influence of Product Quality on Satisfaction Decisions

A competitive advantage in marketing is product quality. Product quality is seen based on product advantages to others to create increased customer satisfaction (P. Kotler \& Armstrong, 2014). A good relationship between producers and consumers will encourage satisfied customers with the products used (Yuniarti, 2016).

Based on previous research conducted by Uzir Hossain Uzir (2020), Nur Dianah (2017) stated that product quality significantly influences customer satisfaction. H4: Product quality has a positive and significant effect on customer satisfaction.

\section{5) The Influence of Price Perception on Satisfaction Decisions}

To meet satisfaction, the customer must spend a set amount of money according to the expected product. Based on the quality aspect, prices are categorized as high or low (P. Kotler \& Armstrong, 2014). The level of customer satisfaction is based on benefits. If the price matches expectations, the customer will feel satisfied. Improper pricing according to benefits can have an impact on decreasing customer satisfaction (Manus \& Lumanauw, 2015).

Based on research conducted by Jonida Xhema (2018), Heryanto (2021) stated that price perception significantly influences customer satisfaction. H5: Price perception has a positive and significant effect on customer satisfaction.

\section{6) The Influence of Brand Image on Satisfaction Decisions}

A direct response regarding good or bad brand recognition is based on customer behavior patterns and memories (Philip Kotler et al., 2019). Brand recognition that gives an attractive impression can influence customers to buy products so that customers feel satisfied (Muharam \& Soliha, 1970).

Based on previous research conducted by Abdulalem Mohammed, Basri Rashid (2018), Fauzian Noor (2020), brand image significantly influences customer satisfaction. H6: Brand image has a positive and significant effect on customer satisfaction.

7) The Influence of Purchasing Decisions on Customer Satisfaction

Purchase decisions will be created when customers feel satisfied or dissatisfied after using the product as expected. Customer satisfaction will not be created if the customer has not purchased the product (P. Kotler \& Armstrong, 2014). The greater the value of the purchase decision thought by the customer, the higher the level of customer satisfaction (Heryanto, 2021).

Based on previous research conducted by Lalinthorn Marakanon (2017), Siti Mabrur Rachmah (2019) states that purchasing decisions significantly influence customer satisfaction. H7: Purchase decisions have a positive and significant effect on customer satisfaction.

\section{8) The Influence of Product Quality on Customer Satisfaction Through Purchase Decisions}

Quality products have an important role in buying decisions and shaping customer satisfaction (Kotler \& Armstrong, 2008). Product quality is one of the considerations in purchasing a good product. Customers will feel satisfied when the purchased product fulfils their wishes (Heryanto, 2021).

Based on previous research conducted by Petr Suchánek, et al. (2016), Suyatmi (2019) stated that quality significantly influences customer satisfaction through purchasing decisions. H8: Product quality has a positive and significant effect on customer satisfaction through purchasing decisions.

\section{9) The Influence of Price Perception on Customer Satisfaction Through Purchase Decisions}

Price specifications are based on value (high, fair, low) which are directly considered by customers (Schiffman \& Kanuk, 2008). The direct influence has an impact on satisfaction in making purchases (Saladin, 2007).

Based on previous research conducted by Osman M. Zaina and Mohammed Bashir Saidub (2016), Hermiyanti Holiza Pakpahan (2019) stated that price perception significantly influences customer satisfaction through purchasing decisions. H9: Price perception has a positive and significant effect on customer satisfaction through purchasing decisions.

10) The Influence of Brand Image on Customer Satisfaction Through Purchase Decisions

The right brand recognition will create customer confidence in purchasing so that customers are satisfied with the brand used and make customers easily remember and recognize the product (P. Kotler \& Armstrong, 2014).

Previous research discusses the influence of brand image on customer satisfaction through purchasing decisions made 
by Abdulalem Mohammed, Basri Rashid (2018), Cristina Calvo-Porrala (2017), and their research results that brand image affects customer satisfaction through purchase decisions. H10: Brand image has a positive and significant effect on customer satisfaction through purchasing decisions.

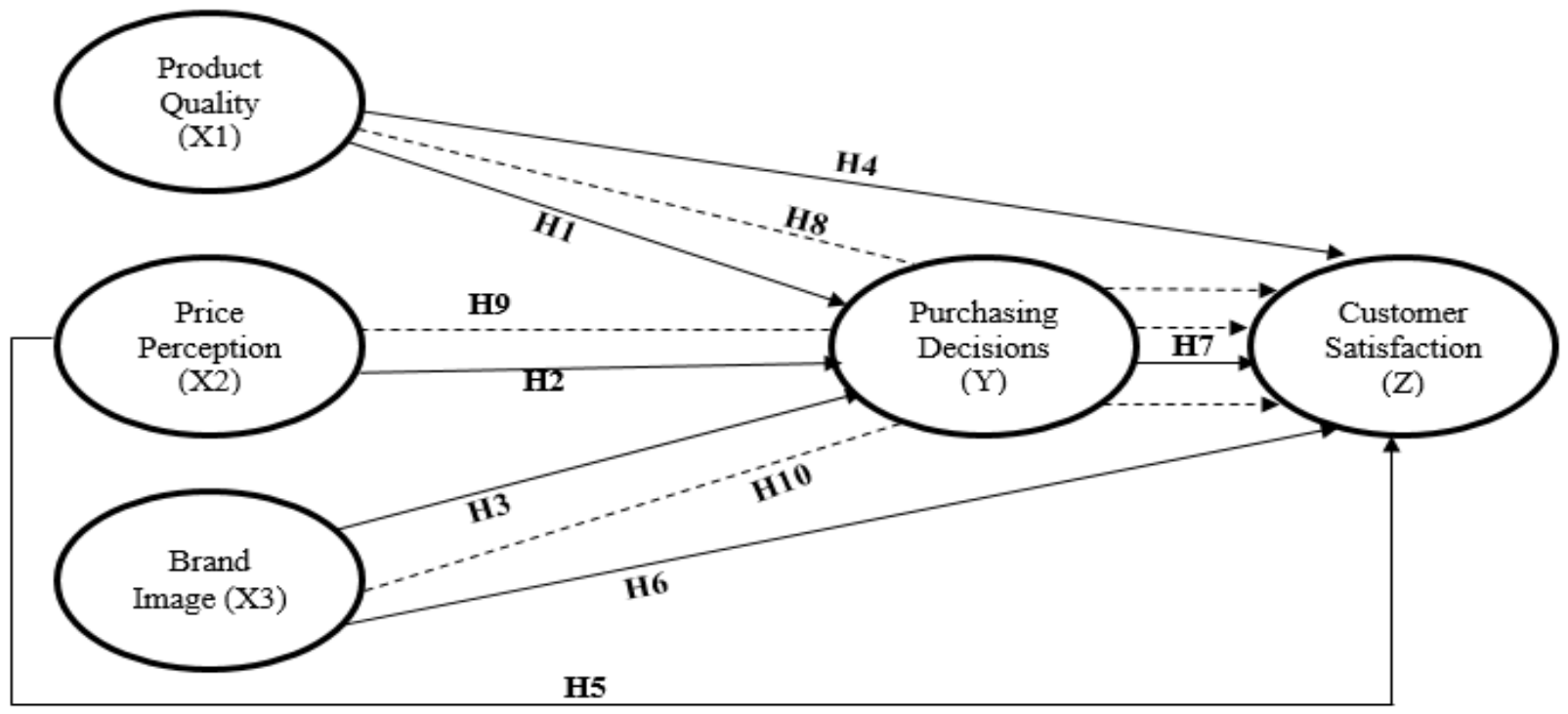

Picture 1. Framework

\section{Research Methodology}

\subsection{Research Design}

This research uses an approach to causal research. This type of data uses quantitative data collection techniques using a questionnaire form with questions to customers. This study looks at the influence of the relationship between variables expressed by data or numbers mathematically using the SEM-PLS data analysis model.

\subsection{Research Time and Place}

The planned research time was carried out and started by the researchers from September to March 2021. The place of research was carried out at the coffee shop outlets of the Kopi Janji Jiwa, Jatiasih area.

\subsection{Population dan Sample}

The target population of the researcher is the customers who have purchased and used the Kopi Janji Jiwa. The sample is based on the purposive sampling technique. The general criteria for the sample are the customers of the Kopi Janji Jiwa or at least have made a purchase or consumed the Kopi Janji Jiwa. The number of samples to be surveyed follows the rules for calculating the Hair formula with the results of the number of data samples by calculating 5 to 10 times the number of indicators for the measurement variable (Ghozali, 2014). The number of customer samples obtained as many as 135 customers.

\section{Results and Discussion}

\section{Respondents Descriptive Analysis}

The result of respondents' descriptive answer, Kopi Janji Jiwa

Table 3. Respondents' Descriptive

\begin{tabular}{clccc}
\hline No & Description & Frequency (People) & Percentage (\%) \\
\hline $\mathbf{1}$ & Gender & & \\
\hline \multirow{2}{*}{} & a. Male & 50 & 59,26 \\
\cline { 2 - 4 } & b. Female & 55 & 40,74 \\
\hline $\mathbf{2}$ & Age & 62 & 45,93 \\
\hline \multirow{2}{*}{} & a. $18-25$ years & 62 & 45,93 \\
\cline { 2 - 4 } & b. $26-35$ years & & \\
\hline
\end{tabular}




\begin{tabular}{|c|c|c|c|}
\hline & c. $36-45$ years & 7 & 5,18 \\
\hline & d. 46 - 55 years & 4 & 2,96 \\
\hline & e. $>55$ years & 0 & 0 \\
\hline \multirow[t]{6}{*}{3} & Last Education & & \\
\hline & a. SMA & 16 & 11,85 \\
\hline & b. Diploma (D3) & 10 & 7,41 \\
\hline & c. Strata Satu (S1) & 105 & 77,78 \\
\hline & d. Strata Dua (S2) & 3 & 2,22 \\
\hline & e. Other & 1 & 0,74 \\
\hline \multirow[t]{6}{*}{4} & Current Job & & \\
\hline & a. Government Employees & 6 & 4,44 \\
\hline & b. Private Employees & 96 & 71,11 \\
\hline & c. Entrepreneur & 10 & 7,41 \\
\hline & d. Student/ College Student & 13 & 9,63 \\
\hline & e. Other & 10 & 7,41 \\
\hline \multirow[t]{6}{*}{5} & Income & & \\
\hline & a. 5 - 10 million & 106 & 78,52 \\
\hline & b. $11-15$ million & 17 & 12,59 \\
\hline & c. $16-20$ million & 3 & 2,22 \\
\hline & d. 21 - 25 million & 2 & 1,48 \\
\hline & e. $>25$ million & 7 & 5,19 \\
\hline
\end{tabular}

Source: data processing results (2021)

Thus it is known that the characteristics of the customers of Kopi Harapan Jiwa that are very dominant are male (59.26\%), female $(40.74 \%)$ with the dominant age category between $18-25$ years (45.93\%) and 26-35. years (45.93\%), with a very dominant S1 education level (77.78\%), with the most dominant background being private employees $(71.11 \%)$, and with a monthly income of $5-10$ million $(78.52 \%)$ is the most dominant.

\section{Measurement Model Testing (Outer Model)}

An indicator is categorized as good and has met convergent validity if it has a value of outer loadings > 0.70 (Ghozali, 2014). Composite reliability (CR) and Cronbach's alpha (CA) testing aims to test the reliability of data collection instruments. If all latent variable values have $C R$ and $C A$ values 0.70 , the construct has good reliability or reliable and consistent data (Ghozali, 2014).

Table 4. Measurement Model Results (outer model)

\begin{tabular}{|c|c|c|c|c|c|}
\hline Construct & $\begin{array}{c}\text { Outer } \\
\text { Loading }\end{array}$ & Mean & $\begin{array}{l}\text { Average } \\
\text { Variance } \\
\text { Extracted }\end{array}$ & $\begin{array}{l}\text { Composite } \\
\text { Reliability }\end{array}$ & $\begin{array}{c}\text { Cronbach's } \\
\text { Alpha }\end{array}$ \\
\hline \multicolumn{6}{|l|}{ Product Quality } \\
\hline $\begin{array}{l}\text { The performance of the product "Kopi Janji Jiwa" } \\
\text { matches my expectations }\end{array}$ & 0.833 & 3,756 & \multirow{4}{*}{0,677} & \multirow{4}{*}{0,840} & \multirow{4}{*}{0,893} \\
\hline $\begin{array}{l}\text { The product "Kopi Janji Jiwa" has several diverse } \\
\text { menu choices }\end{array}$ & 0.731 & 4,096 & & & \\
\hline Product specifications "Kopi Janji Jiwa" as expected & 0.839 & 3,674 & & & \\
\hline $\begin{array}{l}\text { The product "Kopi Janji Jiwa" has good quality and } \\
\text { meets expectations }\end{array}$ & 0.881 & 3,778 & & & \\
\hline \multicolumn{6}{|l|}{ Price Perception } \\
\hline $\begin{array}{l}\text { I feel the price of the product "Kopi Janji Jiwa" is } \\
\text { affordable }\end{array}$ & 0.815 & 3,815 & \multirow{3}{*}{0,765} & \multirow{3}{*}{0,846} & \multirow{3}{*}{0,907} \\
\hline $\begin{array}{l}\text { I feel the price of the product "Kopi Janji Jiwa" is } \\
\text { following the expected product quality }\end{array}$ & 0.914 & 3,837 & & & \\
\hline $\begin{array}{l}\text { I feel that the price of the product "Kopi Janji Jiwa" } \\
\text { is proportional to the benefits offered by the } \\
\text { product }\end{array}$ & 0.891 & 3,696 & & & \\
\hline Brand Image & & & & & \\
\hline
\end{tabular}




\begin{tabular}{|c|c|c|c|c|c|}
\hline $\begin{array}{l}\text { It's easy for me to remember the product "Kopi Janji } \\
\text { Jiwa" when I need coffee }\end{array}$ & 0.764 & 3,415 & \multirow{4}{*}{0,637} & \multirow{4}{*}{0,810} & \multirow{4}{*}{0,875} \\
\hline $\begin{array}{l}\text { I feel that the product "Kopi Janji Jiwa" can } \\
\text { represent the credibility of the brand }\end{array}$ & 0.842 & 3,770 & & & \\
\hline $\begin{array}{l}\text { The product "Kopi Janji Jiwa" can represent my } \\
\text { desire }\end{array}$ & 0.855 & 3,407 & & & \\
\hline $\begin{array}{l}\text { The product brand "Kopi Janji Jiwa" is } \\
\text { following/updated with current developments }\end{array}$ & 0.724 & 3,881 & & & \\
\hline \multicolumn{6}{|l|}{ Purchasing Decisions } \\
\hline $\begin{array}{l}\text { The product "Kopi Janji Jiwa" is one of the first } \\
\text { choices }\end{array}$ & 0.804 & 2,933 & \multirow{4}{*}{0,700} & \multirow{4}{*}{0,857} & \multirow{4}{*}{0,903} \\
\hline $\begin{array}{l}\text { I consider that the product "Kopi Janji Jiwa" has } \\
\text { advantages over other products }\end{array}$ & 0.828 & 3,378 & & & \\
\hline $\begin{array}{l}\text { I decided to buy the product "Kopi Janji Jiwa" } \\
\text { according to my expectations }\end{array}$ & 0.852 & 3,607 & & & \\
\hline $\begin{array}{l}\text { I will recommend the product "Kopi Janji Jiwa" to } \\
\text { others }\end{array}$ & 0.861 & 3,526 & & & \\
\hline \multicolumn{6}{|l|}{ Customers Satisfaction } \\
\hline The product "Kopi Janji Jiwa" can meet my needs & 0.842 & 3,415 & \multirow{4}{*}{0,717} & \multirow{4}{*}{0,867} & \multirow{4}{*}{0,910} \\
\hline $\begin{array}{l}\text { The performance of the product "Kopi Janji Jiwa" is } \\
\text { in line with my expectations }\end{array}$ & 0.883 & 3,511 & & & \\
\hline $\begin{array}{l}\text { The product "Kopi Janji Jiwa" has an advantage over } \\
\text { competitors }\end{array}$ & 0.778 & 3,474 & & & \\
\hline $\begin{array}{l}\text { I am satisfied with all the products presented by } \\
\text { "Kopi Janji Jiwa" }\end{array}$ & 0.880 & 3,578 & & & \\
\hline
\end{tabular}

Source: SmartPLS Data Processing Results (2021)

Based on Table 4, it is known that the value of the outer loading obtained is as recommended, which is 0.70 so that each indicator used in the questionnaire is valid by meeting the requirements of convergent validity, plus consideration of the average variance extracted value for each variable having a value $>0.5$ meetings the value average variance extracted is good for each variable because it has met the discriminant validity requirements. Composite reliability \& Cronbach's alpha values above 0.7 are declared to have good reliability. An indicator is declared valid or meets the requirements of discriminant validity if the value of the cross-loadings indicator on the variable is the largest compared to other variables (Ghozali, 2014).

Table 5. Discriminant Validity Test Result (Cross Loading)

\begin{tabular}{|c|c|c|c|c|c|}
\hline Construct & $\begin{array}{c}\text { Product } \\
\text { Quality }\end{array}$ & $\begin{array}{c}\text { Price } \\
\text { Perception }\end{array}$ & Brand Image & $\begin{array}{c}\text { Purchasing } \\
\text { Decisions }\end{array}$ & $\begin{array}{c}\text { Customers } \\
\text { Satisfaction }\end{array}$ \\
\hline KP-01 & 0.833 & 0.550 & 0.544 & 0.453 & 0.507 \\
\hline KP-02 & 0.731 & 0.445 & 0.477 & 0.417 & 0.477 \\
\hline KP-04 & 0.839 & 0.439 & 0.534 & 0.507 & 0.534 \\
\hline KP-05 & 0.881 & 0.564 & 0.643 & 0.619 & 0.643 \\
\hline PH-01 & 0.432 & 0.815 & 0.481 & 0.435 & 0.499 \\
\hline PH-02 & 0.556 & 0.914 & 0.662 & 0.540 & 0.636 \\
\hline PH-03 & 0.594 & 0.891 & 0.601 & 0.542 & 0.619 \\
\hline CM-02 & 0.375 & 0.455 & 0.764 & 0.653 & 0.494 \\
\hline CM-03 & 0.564 & 0.568 & 0.842 & 0.604 & 0.620 \\
\hline CM-04 & 0.650 & 0.602 & 0.855 & 0.748 & 0.754 \\
\hline CM-05 & 0.543 & 0.505 & 0.724 & 0.477 & 0.519 \\
\hline K-PEM-01 & 0.391 & 0.354 & 0.621 & 0.804 & 0.596 \\
\hline K-PEM-03 & 0.539 & 0.406 & 0.601 & 0.828 & 0.669 \\
\hline K-PEM-04 & 0.645 & 0.582 & 0.727 & 0.852 & 0.742 \\
\hline K-PEM-05 & 0.466 & 0.575 & 0.681 & 0.861 & 0.740 \\
\hline KE-PG-01 & 0.542 & 0.618 & 0.697 & 0.719 & 0.842 \\
\hline KE-PG-02 & 0.689 & 0.604 & 0.684 & 0.704 & 0.883 \\
\hline KE-PG-03 & 0.524 & 0.486 & 0.527 & 0.624 & 0.778 \\
\hline KE-PG-04 & 0.597 & 0.564 & 0.654 & 0.743 & 0.880 \\
\hline
\end{tabular}




\section{Source: Smart PLS Output Data Processing (2021)}

The calculation of the Fornell Larcker criterion states that the result of the variable value is greater than the value of the relationship with other variables. The discriminant validity value is declared both based on Cross loading and the Fornell Larcker Criterion, so the category is good.

Table 6. Discriminant Validity Test Result (Fornell Larcker Criterion)

\begin{tabular}{|c|c|c|c|c|c|}
\hline Construct & $\begin{array}{c}\text { Product } \\
\text { Quality }\end{array}$ & $\begin{array}{c}\text { Price } \\
\text { Perception }\end{array}$ & $\begin{array}{c}\text { Brand } \\
\text { Image }\end{array}$ & $\begin{array}{c}\text { Purchasing } \\
\text { Decisions }\end{array}$ & $\begin{array}{c}\text { Customers } \\
\text { Satisfaction }\end{array}$ \\
\hline Product Quality & 0.823 & & & & \\
\hline Price Perception & 0.609 & 0.875 & & & \\
\hline Brand Image & 0.674 & 0.671 & 0.798 & & \\
\hline Purchasing Decisions & 0.616 & 0.582 & 0.789 & 0.836 & \\
\hline Customers Satisfaction & 0.697 & 0.673 & 0.760 & 0.826 & 0.847 \\
\hline
\end{tabular}

Source: SmartPLS Output Data Processing (2021)

\section{Structural Module Testing (Inner Model)}

The coefficient of determination R-Square (R2) determines how much influence the independent latent variable has on the dependent latent variable. R-Square models with above 0.7 are categorized as strong. Those below 0.67 are categorized as moderate.

Table 7. Test Result $R$-Square

\begin{tabular}{lc}
\hline & R-Square \\
\hline Purchasing Decisions & 0,637 \\
\hline Customers Satisfaction & 0,765 \\
\hline
\end{tabular}

Source: SmartPLS Output Data Processing Results (2021)

Based on table 8, it is known that the variable model on the purchasing decision variable is included in the moderate category because the R-Square value is 0.637 . As for the model on the customer, the satisfaction variable is included in the strong category because the R-Square value has a value above 0.7 , which is 0.765 .

Based on the results of the Q-Square test, a value of 0.850 is obtained, meaning that the prediction capability of this model is large, namely $85.0 \%$ so that the model is feasible to use. The calculation value is the GoF value of 0.70 so that the model can be said to be fit or has great relevance between the measurement model and the structural model (inner model).

\section{Hypotheses Test}

The Bootstrapping calculation procedure can obtain hypothesis testing. Significant or insignificant value using t-table value at alpha 0.05 (level $5 \%$ ) of 1.96 with t-table compared to T-statistics (count).

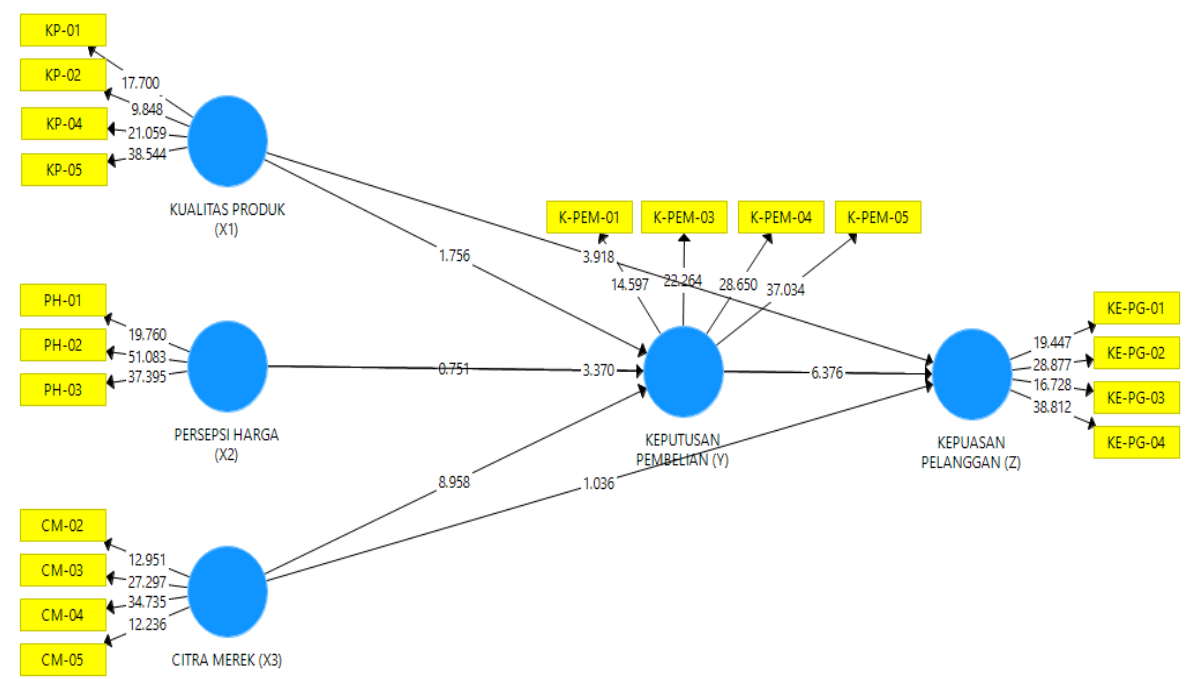

Picture 2. Path Diagram Results with Bootstrapping

Source: SmartPLS Data Processing (2021) 
Table 8. Hypotheses Test Result

\begin{tabular}{|l|l|c|c|c|}
\hline & & Coefficient & T Statistics & Conclusion \\
\hline H1 & Product Quality -> Purchasing Decisions & 0,139 & 1,756 & Rejected \\
\hline H2 & Price Perception -> Purchasing Decisions & 0,056 & 0,751 & Rejected \\
\hline H3 & Brand Image -> Purchasing Decisions & 0,658 & 8,958 & Accepted \\
\hline H4 & Product Quality -> Customers Satisfaction & 0,202 & 3,918 & Accepted \\
\hline H5 & Price Perception -> Customers Satisfaction & 0,189 & 3,370 & Accepted \\
\hline H6 & Brand Image -> Customers Satisfaction & 0,081 & 1,036 & Rejected \\
\hline H7 & Purchasing Decisions -> Customers Satisfaction & 0,527 & 6,376 & Accepted \\
\hline H8 & $\begin{array}{l}\text { Product Quality -> Customers Satisfaction -> } \\
\text { Purchasing Decisions }\end{array}$ & 0,073 & 1,602 & Rejected \\
\hline H9 & $\begin{array}{l}\text { Price Perception -> Customers Satisfaction -> } \\
\text { Purchasing Decisions }\end{array}$ & 0,029 & 0,743 & Rejected \\
\hline H10 & $\begin{array}{l}\text { Brand Image -> Customers Satisfaction -> } \\
\text { Purchasing Decisions }\end{array}$ & 0,347 & 5,461 & Accepted \\
\hline
\end{tabular}

Source: SmartPLS Output Data Processing Results (2021)

\section{Discussion}

The results of the first hypothesis are rejected. Product quality is identified as having a positive and insignificant effect on purchasing decisions. This resembles research conducted by Diana (2019) stated that product quality does not significantly influence Starbucks' purchasing decisions. However, it is not in line with Nor Hazlin Nor Asshidin (2016) research, which states that product quality affects and is significant on purchasing decisions. Product quality on purchasing decisions is not a factor that triggers purchases with only an influence of $13.9 \%$ and the $t$-count value is smaller than the t-table, namely 1.756 .

The results of the second hypothesis are rejected. Price perceptions are identified as having a positive and insignificant effect on purchasing decisions. This is in line with research conducted by Diana (2020), which states that price perception does not significantly influence Starbucks' purchasing decisions. However, it is not in line with the research of Lucian Pitic, et al (2017), Owusu Alfred (2013) which states that price perception has an effect and is significant on purchasing decisions. Price perception on purchasing decisions is not a trigger factor for purchases with only an influence of $5.6 \%$ and the t-count value is smaller than the t-table, which is 0.751 .

The results of the third hypothesis are accepted. Brand image is identified as having a positive and significant influence on purchasing decisions. In line with research conducted by Albari, et al. (2020), Cristina Calvo-Porral (2017) states that brand image has a significant and influential effect on purchasing decisions. The brand image on purchasing decisions is one of the main trigger factors in purchasing with only influencing $65.8 \%$ and the t-count value is greater than the t-table which is 8.958 . The indicator on the brand image on purchasing decisions has the lowest average value on the Kopi Janji Jiwa product that can represent my wishes so that to improve purchasing decisions. The Kopi Janji Jiwa needs to increase brand recognition to create a positive impression given by Kopi Janji Jiwa so that customers are loyal to Coffee. Kopi Janji Jiwa not to switch to other business competitors.

The results of the fourth hypothesis are accepted. Product quality is identified to have a positive and significant influence on customer satisfaction. In line with Uzir Hossain Uzir (2020) research, Nur Dianah (2017) states that product quality has a significant and significant effect on customer satisfaction. Product quality on customer satisfaction has a trigger factor that can affect customer satisfaction by $20.2 \%$ with a t value of 3.918 , greater than the t-table. Product quality indicators on customer satisfaction have the lowest average on the specifications of the Kopi Janji Jiwa product as expected so that the Kopi Janji Jiwapays attention to the specifications of the type of coffee/coffee flavor that is used with the best quality, making customers feel satisfied with Kopi Janji Jiwa product.

The results of are the fifth hypothesis accepted, price perception is identified as having a positive and significant effect on customer satisfaction. In line with research conducted by Jonida Xhema, et al. (2018), and Heryanto (2021) stated that price perception has a significant and significant effect on customer satisfaction. Price perception on customer satisfaction has a trigger factor that can affect customer satisfaction by $18.9 \%$ with the $\mathrm{t}$-count value of 3.370 which is greater than the $t$-table. The indicator of price perception on customer satisfaction has the lowest average. I feel that the price of the product of Kopi Janji Jiwa is proportional to the benefits offered by the product so that the Kopi Janji Jiwa needs to consider the perception of the price given to customers of Kopi Janji Jiwa according to the quality of taste that the customer expects. 
The results of the sixth hypothesis are rejected. Brand image is identified as having a positive and insignificant effect on customer satisfaction. In line with the research conducted by Abdulalem Mohammed \& Basri Rashid (2018), it is stated that brand image has no and significant effect on customer satisfaction. However, this is not in line with Fauzian Noor's (2020) research, which states that brand image has an effect and is significant on customer satisfaction. The brand image on customer satisfaction is not a trigger factor that can affect customer satisfaction by $8.1 \%$ with the $t$-count value of 1.036 which is smaller than the t-table.

The results of the seventh hypothesis are accepted. Purchasing decisions are identified as having a positive and significant influence on customer satisfaction. In line with research conducted by Lalinthorn Marakanon (2017), Siti Mabrur (2019), states that purchasing decisions have an effect and are significant on customer satisfaction. Purchasing decisions on customer satisfaction have trigger factors that can affect customer satisfaction by $57.7 \%$, with the t-count value of 6.376 which is greater than the t-table. The indicator of purchasing decisions on customer satisfaction has the lowest average on the Kopi Janji Jiwa product being one of the first choices, so the Kopi Janji Jiwa needs to pay attention to customer satisfaction. The greater the value of the purchase decision thought by the customer, the higher the level of customer satisfaction.

The results of the eighth hypothesis are rejected. Product quality is identified as having a positive and insignificant effect on customer satisfaction through purchasing decisions. In line with research conducted by Novita Nurul (2020), that product quality has no significant effect on Starbucks customer satisfaction. However, this is not in line with the research of Petr Suchánek, et al. (2016), which states that product quality has a significant and significant effect on customer satisfaction through purchasing decisions. Product quality on customer satisfaction through purchasing decisions is not a trigger factor that can affect customer satisfaction by $7.3 \%$ with the $t$-count value of 1.602 which is smaller than the t-table.

The results of the ninth hypothesis are rejected. Price perception is identified as having a positive and insignificant effect on customer satisfaction through purchasing decisions. In line with Ratlan Pardede (2017) research, it states that price perception does not significantly affect customer satisfaction through purchasing decisions. However, it is not in line with Osman M. Zaina \& Mohammed Bashir Saidub (2016) research, which states that price perception significantly affects customer satisfaction through purchasing decisions. Price perception on customer satisfaction through purchasing decisions is not a trigger factor that can affect customer satisfaction by $2.9 \%$ with a t value of 0.743 which is smaller than the t-table.

The results of the tenth hypothesis are accepted. Brand image is identified as having a positive and significant influence on customer satisfaction through purchasing decisions. In line with the research of Cristina Calvo-Porrala, et al. (2017), stated that brand image has a significant and significant effect on customer satisfaction through purchasing decisions. Purchasing decisions on customer satisfaction through purchasing decisions have trigger factors that can affect customer satisfaction by $34.7 \%$ with a $t$ value of 5.461 , which is greater than the $t$ table. The indicator of purchasing decisions on customer satisfaction has the lowest average of Kopi Janji Jiwa products that can represent my wishes so that Kopi Janji Jiwa prioritizes customer satisfaction to give a positive impression about the Kopi Janji Jiwa brand that adapts to current developments.

\section{Conclusion and Suggestions}

\subsection{Conclusion}

1. Product quality variable has a positive and insignificant effect on purchasing decisions. Thus, product quality in purchasing decisions is not a trigger factor for customers in determining the purchasing decision of Kopi Janji Jiwa.

2. The price perception variable has a positive and insignificant effect on purchasing decisions. Thus, the perception of price in purchasing decisions is not a trigger factor for customers in determining the purchasing decision of Kopi Janji Jiwa.

3. Brand image variable has a positive and significant influence on purchasing decisions. Thus, a brand image in purchasing decisions is one of the trigger factors for customers in determining the purchasing decision of Kopi Janji Jiwa.

4. Product quality variable has a positive and significant effect on customer satisfaction. Thus, product quality in customer satisfaction is one of the triggering factors for customers determining customer satisfaction.

5. The price perception variable has a positive and significant effect on customer satisfaction. Thus, the perception of price in customer satisfaction triggers customers in determining customer satisfaction.

6. Brand image variable has a positive and insignificant effect on customer satisfaction. Thus, the brand image in customer satisfaction is not a trigger factor for customers in determining the customer satisfaction of Kopi Janji Jiwa.

7. The purchase decision variable has a positive and significant effect on customer satisfaction. Thus, purchasing decisions in customer satisfaction become a trigger factor for customers in determining customer satisfaction.

8. Product quality variable has a positive and insignificant effect on customer satisfaction through purchasing 
decisions. Thus, product quality on customer satisfaction through purchasing decisions is not a trigger factor for customers determining customer satisfaction for Kopi Janji Jiwa.

9. The price perception variable has a positive and insignificant effect on customer satisfaction through purchasing decisions. Thus, the perception of price on customer satisfaction through purchasing decisions is not a trigger factor for customers determining customer satisfaction for Kopi Janji Jiwa.

10. Brand image variable has a positive and significant influence on customer satisfaction through purchasing decisions. Thus, the brand image on customer satisfaction through purchasing decisions is one of the triggering factors for customers in determining customer satisfaction.

\subsection{Suggestion}

From the study results and based on the conclusions above, the following suggestions can be given.

1) For the Kopi Janji Jiwa Company

- It is known that the brand image variable on the indicator "Kopi Janji Jiwa product can represent my desire" has the lowest average value. Thus, in influencing the purchase decision variable, it is a very dominant factor, so that Kopi Janji Jiwa needs to evaluate brand recognition to customers to improve customer purchasing decisions.

- Product quality variable, the indicator "Kopi Janji Jiwa product specifications" as expected" has the lowest average value. Thus, product quality in influencing customer satisfaction variables is a very dominant factor, so that Kopi Janji Jiwaparty pays attention to product quality aspects to be able to meet customer satisfaction.

- Kopi Janji Jiwa needs to consider price perception. The price perception variable is known, so the indicator "I feel that the price of the Kopi Janji Jiwa product is proportional to the benefits offered by the product" has the lowest average value. Thus, the perception of price in influencing the variable of customer satisfaction is one of the dominant factors, so that it becomes a consideration to meet customer satisfaction. In this case, Kopi Janji Jiwa can adjust to the quality of taste expected by the customer.

- The purchase decision variable is known, so the indicator "Kopi Janji Jiwa is one of the first choices" has the lowest average value. Thus, without a purchase decision, there will be no sense of consumer satisfaction. The greater the value of the purchase decision thought by the customer, the higher the level of customer satisfaction.

- - If the brand image variable is known, the indicator "Kopi Janji Jiwa product can represent my desire" has the lowest average value. Thus, the Kopi Janji Jiwa party needs to evaluate the product brand image of the Kopi Janji Jiwa to be an essential factor in giving a good impression to customers.

2) For further research:

To increase customer satisfaction, Kopi Janji Jiwa cannot be done by only increasing the factors that trigger brand image, price perception, and product quality, so it is necessary to pay attention to aspects that can improve customer decisions and customer satisfaction.

\section{References}

[1] Albari, A. (2020). The Influence of Product Price on Consumers' Purchasing Decisions. 7, 328-337.

[2] Alfred, O. (2013). Influences of Price And Quality On Consumer Purchase Of Mobile Phone In The Kumasi Metropolis In Ghana A Comparative Study. European Journal of Business and Management, 5(1), 179-198.

[3] Amili, S., \& Nst, M. O. A. (2017). Pengaruh Citra Merek, Harga, dan Kualitas Produk terhadap Keputusan Pembelian Handphone Merek Xiaomi di Kota Langsa. Jurnal Manajemen Dan Keuangan, 6(1), 660-669.

[4] Ariyuni, D., \& Suhardi, Y. (2020). Pengaruh Persepsi Harga, Kualitas Pelayanan, dan Word Of Mouth Terhadap Keputusan Pembelian (Studi pada Starbucks Coffee Stasiun Gambir). Jurnal STEI Ekonomi, 22(11).

[5] Asshidin, N. H. N., Abidin, N., \& Borhan, H. B. (2016). Perceived Quality and Emotional Value that Influence Consumer's Purchase Intention towards American and Local Products. Procedia Economics and Finance, 35, 639-643. https://doi.org/10.1016/S22125671(16)00078-2

[6] Aulia, S. (2016). Pengaruh Kualitas Produk, Harga, dan Lokasi Terhadap Keputusan Pembelian. Jurnal Pendidik Tata Niaga, 4(3).

[7] Ávila, L. V., Leal Filho, W., Brandli, L., Macgregor, C. J., Molthan-Hill, P., Özuyar, P. G., \& Moreira, R. M. (2017). Barriers to innovation and sustainability at universities around the world. Journal of Cleaner Production, 164, 1268-1278. https://doi.org/10.1016/j.jclepro.2017.07.025

[8] Calvo-Porral, C., \& Lévy-Mangin, J.-P. (2017). Store brands' purchase intention: Examining the role of perceived quality. European Research on Management and Business Economics, 23(2), 90-95. https://doi.org/10.1016/j.iedeen.2016.10.001

[9] Dianah, N., \& Welsa, H. (2017). PENGARUH KUALITAS PRODUK DAN CITRA MEREK TERHADAP KEPUTUSAN PEMBELIAN SMARTPHONE XIAOMI SERTA DAMPAKNYA PADA KEPUASAN KONSUMEN. Jurnal Manajemen; Vol 7 No 1 (2017): JURNAL MANAJEMEN VOL. 7 NO. 1 JUNI 2017DO - 10.26460/Jm.V7i1.240. https://jurnalfe.ustjogja.ac.id/index.php/manajemen/article/view/240

[10] Efendi, A. F., \& Rois Arifin, M. H. (2018). Pengaruh Brand Image, Kualitas Produk, dan Harga Terhadap Keputusan Pembelian Sepatu Nike. Jurnal Ilmiah Riset Manajemen, 7(6). 
[11] Ghozali, I. (2014). Structural Equation Modeling Metode Alternatif dengan Partial Least Squares (PLS). Universitas Dipenegoro Semarang.

[12] Gulanang, M. G., \& Pramudena, S. M. (2019). Analisis Kualitas Produk dan Citra Merek terhadap Keputusan Pembelian dan Implikasinya Pada Kepuasan Pelanggan PT. Wilo Pumps Indonesia. E-Jurnal Universitas Mercubuana, 3(3). https://doi.org/10.22441/indikator.2019.v3i3.006

[13] Gunawan, G. (2020). Pengaruh Kualitas Layanan Dan Kualitas Produk Terhadap Kepuasan Pelanggan Kedai Kopi Kulo Kelapa Gading. nstitut Bisnis dan Informatika Kwik Kian Gie.

[14] Heryanto, I. (2021). ANALISIS PENGARUH PRODUK, HARGA, DISTRIBUSI, DAN PROMOSI TERHADAP KEPUTUSAN PEMBELIAN SERTA IMPLIKASINYA PADA KEPUASAN PELANGGAN . Jurnal Ekonomi, Bisnis \&amp; Entrepreneurship, 9(2 SE-Artikel). https://jurnal.stiepas.ac.id/index.php/jebe/article/view/54

[15] Kotler, P., \& Armstrong, G. (2014). Prinsip-Prinsip Pemasaran. Erlangga.

[16] Kotler, Philip., Armstrong, G., Yasin., N. M., Jaffar., G., \& Ariffin., A. A. M. (2000). Prinsip pemasaran. Prentice Hall.

[17] Kotler, Philip, Keller, K. L., Brady, M., Goodman, M., \& Hansen, T. (2019). Marketing management.

[18] Manus, F. W., \& Lumanauw, B. (2015). Kualitas Produk, Harga, dan Kualitas Layanan, Pengaruhnya Terhadap Kepuasan Pelanggan Kartu Prabayar Tri di Kelurahan Wawalintouan Tondano Barat. Jurnal Manajemen Ekonomi Dan Bisnis, 3(2).

[19] Marakanon, L., \& Panjakajornsak, V. (2017). Perceived quality, perceived risk and customer trust affecting customer loyalty of environmentally friendly electronics products. Kasetsart Journal of Social Sciences, 38(1), 24-30. https://doi.org/10.1016/j.kjss.2016.08.012

[20] Marie, A. L., \& Budi, A. (2020). Analisis Pengaruh Kualitas Produk Terhadap Kepuasan Pelanggan Kopi Kenangan The Breeze, Bumi Serpong Damai. Jurnal Ilmiah Pariwisata; Vol 25 No 2 (2020): Jurnal Ilmiah PariwisataDO - 10.30647/Jip.V25i2.1341. http://jurnalpariwisata.stptrisakti.ac.id/index.php/JIP/article/view/1341

[21] Mohammed, A., \& Rashid, B. (2018). A conceptual model of corporate social responsibility dimensions, brand image, and customer satisfaction in Malaysian hotel industry. Kasetsart Journal of Social Sciences, 39(2), 358-364. https://doi.org/10.1016/j.kjss.2018.04.001

[22] Muharam, W., \& Soliha, E. (1970). KUALITAS PRODUK, CITRA MEREK, PERSEPSI HARGA DAN KEPUTUSAN PEMBELIAN KONSUMEN HONDA MOBILIO. Proceeding SENDI_U, O(0 SE-Articles). https://www.unisbank.ac.id/ojs/index.php/sendi_u/article/view/5100

[23] Noor, F., Utari, W., \& Mardi W., N. (2020). PENGARUH KUALITAS PRODUK, PERSEPSI HARGA CITRA MEREK TERHADAP KEPUTUSAN PEMBELIAN SERTA DAMPAKNYA TERHADAP KEPUASAN KONSUMEN (STUDI PADA KONSUMEN PRODUK PT. SALIM IVOMAS PRATAMA KECAMATAN BOJONEGORO KABUPATEN BOJONEGORO). Jurnal Mitra Manajemen, 4(4), 581-594. https://doi.org/10.52160/ejmm.v4i4.374

[24] Novita, N., \& Agustian, B. (2020). Pengaruh Kualitas Pelayanan, Kualitas Produk, dan Citra Merek Terhadap Kepuasan Konsumen Starbucks Grand Indonesia. Sekolah Tinggi Ilmu Ekonomi Indonesia Jakarta.

[25] Pakpahan, H. H. (2019). Analisis Pengaruh Kualitas Produk, Harga Dan Ketersediaan Produk Terhadap Keputusan Pembelian Dan Implikasinya Pada Kepuasan Konsumen Obat Sakit Kepala. Universitas Mercu Buana Jakarta.

[26] Pardede, R., \& Haryadi, T. Y. (2017). PENGARUH PERSEPSI HARGA DAN KUALITAS PRODUK TERHADAP KEPUTUSAN PEMBELIAN KONSUMEN YANG DIMEDIASI KEPUASAN KONSUMEN. Journal of Business \& Applied Management, 10(1). https://doi.org/10.30813/jbam.v10i1.870

[27] Rayni Delya, H. (2020). PANDANGAN CITRA BRAND KOPI JANJI JIWA DI KALANGAN MAHASISWA. Jurnal Ilmiah Komunikasi Makna 8(1), 12. https://doi.org/10.30659/jikm.v8i1.7977

[28] Saladin, D. (2007). Manajemen Pemasaran. Linda Karya.

[29] Schiffman, L. G., \& Kanuk, L. L. (2008). Perilaku konsumen. Jakarta: Indeks. http://opac.library.um.ac.id/oaipmh/../index.php?s_data=bp_buku\&s_field=0\&mod=b\&cat=3\&id=53339

[30] Sejati, B. S. A., \& Yahya, Y. (2016). Pengaruh Kualitas Produk, Kualitas Layanan, dan Harga Terhadap Keputusan Pembelian Pada Starbucks. Jurnal Ilmu Dan Riset Manajemen, 5(3).

[31] Siti Mabrur, R. (2019). Analisis Citra Merek, Kualitas Produk, dan Promosi Terhadap Keputusan Pembelian serta implikasinya terhadap Kepuasan Pelanggan Produk Buku Balai Pustaka. Universitas Mercu Buana.

[32] Soebakir, B. D., Lumanauw, B., \& Roring, F. (2018). Pengaruh Brand, Harga, Dan Kualitas Pelayanan Terhadap Keputusan Pelanggan Membeli di kedai Kopi Gudang Imaji Manado. Jurnal EMBA: Jurnal Riset Ekonomi, Manajemen, Bisnis Dan Akuntansi, 6(4). https://doi.org/https://doi.org/10.35794/emba.v6i4.21910

[33] Soleh, H. (2017). Transformasi Uang Model Karl Marx Perspektif Konsep Uang dalam Ekonomi Islam. Inovatif, 3(1), 137-153.

[34] Suchánek, P., Richter, J., \& Králová, M. (2016). Customer Satisfaction with Quality of Products of Food Business. Prague Economic Papers, 26, 1-17. https://doi.org/10.18267/j.pep.595

[35] Suyatmi, S., \& Sitio, A. (2019). Analisa Pengaruh Kualitas Produk dan Saluran Distribusi terhadap Keputusan Pembelian serta Implikasinya pada Kepuasan Pelanggan PT. Widodo Makmur Perkasa. Indikator: Jurnal Ilmiah Manajemen Dan Bisnis, 3(1), $109-121$. https://doi.org/https://dx.doi.org/10.22441/indikator.v3i1.5171

[36] Tjiptono, F. (2014). Pemasaran Jasa: Prinsip, Penerapan, Penelitian. Andi.

[37] Tjiptono, F., \& Diana, A. (2019). Kepuasan Pelanggan, Konsep, Pengukuran dan Strategi. Yogyakarta. ANDI.

[38] Uzir, M. U. H., Jerin, I., Al Halbusi, H., Hamid, A. B. A., \& Latiff, A. S. A. (2020). Does quality stimulate customer satisfaction where perceived value mediates and the usage of social media moderates? Heliyon, 6(12), e05710. https://doi.org/10.1016/j.heliyon.2020.e05710

[39] Xhema, J., Metin, H., \& Groumpos, P. (2018). Switching-Costs, Corporate Image and Product Quality effect on Customer Loyalty: Kosovo Retail Market. IFAC-PapersOnLine, 51(30), 287-292. https://doi.org/10.1016/j.ifacol.2018.11.303

[40] Yuniarti, Y. (2016). Pengaruh Kualitas Produk, Harga dan Kepercayaan terhadap Keputusan Pembelian Produk Fashion secara Online. Jurnal Penelitian Universitas Jambi: Seri Humaniora, 18(1).

[41] Zain, O. M., \& Saidu, M. B. (2016). The Customers Satisfaction on Retailers' Brand Products: A Study on Selected Areas in Klang Valley. Procedia Economics and Finance, 35, 418-427. https://doi.org/10.1016/S2212-5671(16)00052-6 